\title{
IMPROVEMENT OF LIFE QUALITY USING NATURE BASED \\ SOLUTIONS - CASE STUDY SETTLEMENTS \\ IN SOUTH-EASTERN SERBIA
}

DOI: 10.18485/arh_pt.2020.7.ch64

\section{_ Milica Igić}

PhD student, Assistant, University of Niš, Faculty of Civil Engineering and Architecture,

Aleksandra Medvedeva street 14, 18000 Niš, Serbia, milica.igic989@gmail.com

\section{- Petar Mitković}

PhD, Full Professor, University of Niš, Faculty of Civil Engineering and Architecture,

Aleksandra Medvedeva street 14, 18000 Niš, Serbia, petar.mitkovic@gaf.ni.ac.rs

\section{Milena Dinić Branković}

PhD, Assistant Professor, University of Niš, Faculty of Civil Engineering and Architecture, Aleksandra Medvedeva street 14, 18000 Niš, Serbia, milena.dinic@gaf.ni.ac.rs

\section{_ Jelena Đekić}

PhD student, Assistant, University of Niš, Faculty of Civil Engineering and Architecture, Aleksandra Medvedeva street 14, 18000 Niš, Serbia, jelena_djuric@ymail.com

\section{_ Ivana Bogdanović Protić}

PhD, Assistant Professor, University of Niš, Faculty of Civil Engineering and Architecture, Aleksandra Medvedeva street 14, 18000 Niš, Serbia, ivana.bogdanovic@gaf.ni.ac.rs

\section{_ Milica Ljubenović}

PhD student, Assistant, University of Niš, Faculty of Civil Engineering and Architecture, Aleksandra Medvedeva street 14, 18000 Niš, Serbia, milica.stj@gmail.com

\section{Mihailo Mitković}

PhD student, Assistant, University of Niš, Faculty of Civil Engineering and Architecture, Aleksandra Medvedeva street 14, 18000 Niš, Serbia, mihailo.mitkovic@yahoo.com

\section{ABSTRACT}

Due to ongoing urbanization process and uncontrolled migration from rural to urban areas, city territory is spreading constantly without proper infrastructure development. This is one of the global problems and one of the main characteristics of post-socialist cities in the region. During Socialism, and later transition period, earlier rural settlements became part of city urban territory, but still remained rural in character - both spatially and functionally. On the other hand, because of expressed depopulation and degradation processes in villages and small rural settlements, quality of living conditions is significantly decreased and they became less attractive for living. Another threat to modern society and quality of life, is certainly climate change (CC) which affects both urban and rural areas. This paper discusses possibilities of life quality improvement by using nature based solutions (NBS). Different type of rural settlements in south-eastern Serbia will be analysed in order to determine possibilities for improvement of life quality and wellbeing of the residents. The aim of this paper is to investigate current state and problems these settlements are facing, and to discuss possibilities for use of NBS in order to create better places for residents. In order to improve quality of life, increase resilience of rural settlements and implement adequate and efficient NBS, it is im- 
portant to have multidisciplinary and comprehensive approach. Because life quality improvement is a long term process, analyses must take into account spatial, functional and social dimensions of one settlement and consider all the opportunities and all possible setbacks. Analyses and implementation plans must be conducted for each settlement locally - must be customized for every settlement depending on the specific spatial, development and natural context. Because all the settlements are facing increasing negative impacts of CC, use of NBS can be efficient "tool" for CC mitigation and adaptation.

KEYWORDS _ quality of life, nature based solutions, rural settlements, climate change

\section{INTRODUCTION}

Rapid process of urbanization led to uncontrolled spreading of city's territory and as a result of this process, many rural settlements became parts of the suburbia, during time received the status of suburban settlements but remained with rural character - without proper infrastructure and low life quality. These former rural settlements are characterized by completely unconstrained territory spreading, narrow and irregular street network, densely constructed objects and no green areas, which have negatively influenced life quality, health of residents and wellbeing in general. Other rural settlements which are not adjacent to the urban territory, and those which are remote, are not overpopulated and still characterized by very rich natural resources, but because of intensive depopulation process and lack of basic infrastructure, life quality decreased significantly. Because of spatial and physical characteristics of rural settlements, there is a great impact of CC which is also having negative effects on the life quality. Overheating of surfaces without greenery has negative impact on thermal comfort, river streams are causing floods which can be contagious because of unregulated sewage and atmospheric runoff water systems, and represent great threat both to human lives and agriculture crops. This paper discusses use of NBS in rural settlements within area of south-eastern Serbia - large village: Gornji Matejevac, suburban settlement: Donja Vrežina and rural settlements seats of the municipalities: Trgovište and Gadžin Han. Use of these solutions would benefit in terms of increasing life conditions and also in terms of adapting to the one of the greatest threats - CC. The aim of this paper is to investigate current state in these settlements and to analyse possible improvement of life quality and human wellbeing by using NBS. The methodological framework is based on an analytical approach which relies on description and observation of current state in these settlements, analysis and suggestions for possible solutions. Rural settlements were chosen because about $2 / 3$ of Serbian territory is rural, these areas have rich natural resources and they are facing negative impacts of $\mathrm{CC}$ which is much expressed. One of the criteria for case studies was population size - chosen settlements are categorized as medium and large. Another criteria was spatial and functional structure - all are community centres of the surrounding settlements. They differ in term of their location toward urban area and they are in different districts within south-eastern Serbia. Based on the analysis of their spatial characteristics, different solutions are proposed and future environmental and social impacts - benefits were highlighted.

\section{BACKGROUND: NATURE BASED SOLUTIONS AND CLIMATE CHANGE}

Nature and the city were always connected through history and there were many ideas of bringing the nature into the cities. One of these ideas was Howards (1898) utopian - garden city which represents intermediate form which takes the best from the city and countryside and promotes "ideal" place for living surrounded with nature. Concept of NBS "emerged" after 2000, and nature solutions were considered as a "tool" for helping society to face great challenges caused by negative impact 
of CC. NBS were further addressed and developed by International Union for Conservation of Nature (IUCN) and European Commission (EC). There are two widely used definitions of NBS: a) definition by IUCN (Cohen-Shacham, 2016) "actions to protect, sustainably manage and restore natural or modified ecosystems that address societal challenges effectively and adaptively, simultaneously providing human well-being and biodiversity benefits"; b) definition by EC (2015) "actions inspired by, supported by or copied from nature; both using and enhancing existing solutions to challenges, as well as exploring more novel solutions, for example, mimicking how non-human organisms and communities cope with environmental extremes. Nature-based solutions use the features and complex system processes of nature, such as its ability to store carbon and regulate water flows, in order to achieve desired outcomes, such as reduced disaster risk and an environment that improves human well-being and socially inclusive green growth". According to Maes and Jacobs (2015), NBS can be also defined as "any transition to a use of ecosystem services with decreased input of non-renewable natural capital and increased investment in renewable natural processes". Beside IUCN reports, NBS solutions were part of the World Bank report (MacKinnon et al, 2008), and they represent a core of EU R\&I Programme for H2020. NBS solutions were part of the IUCN Programme for 2013-2016 (IUCN, 2013).

Depending on the level of the involvement of engineering of biodiversity and ecosystems, and number of ecosystem services and stakeholders groups that are targeted by NBS, 3 types of NBS solutions are defined: 1- use of NBS with minimal intervention; 2- use of NBS for sustainability and multifunctionality of managed and restored ecosystems and for innovative planning of farming land; 3- for designing and managing new or existing ecosystems on very "intrusive" way (Eggermont et al, 2015). These 3 types are overlapping and clear division cannot be defined. Use of NBS is often related to innovative solutions, but it should also rely on traditional knowledge and local resources. NBS represent one of the human scaled solutions which are aimed to improve human wellbeing on different levels. NBS are defined with 8 principles and they are considered as "umbrella" for other ecosystem-related approaches. These concepts can be divided into 2 groups - those that represent problem solving techniques and concepts that are "approaches to management". All concepts related to NBS are interrelated, they are characterized by similar principles of multifunctionality and participation, but they differ in terms of implementation in planning processes and practice solutions, and in terms of coverage - comprehensiveness of principles (Pauleit et al, 2017; Nesshöver, 2017). NBS can be used to help humans to face major societal challenges of today, and it is considered as an efficient tool for CC mitigation and adaptation at various scales (EC, 2015). Using NBS, grey, blue and green infrastructure could be integrated, which could result in improving natural components, social wellbeing and economy. Use of NBS for mitigation and adaptation can also contribute to positive effects of health outcomes and in improving of wellbeing in general and it can improve mental health and help in reducing stress of residents (Kabisch \& Annerstedt van den Bosch, 2017; Vujčić et al, 2017). NBS has also positive impact on social cohesion, implementing some of the NBS can contribute to increasing of social contacts and cohesion and to create more climate-resilient cities (Rutt \& Gulsrud, 2016). NBS can have role in making urbanisation process more "sustainable" and in effectiveness of responsible facing ongoing challenges of modern society, and can contribute in creating more resilient cities and landscapes (Lafortezza et al, 2018; Lafortezza \& Sanesi, 2019). It can also improve food security - manage agriculture land in rural areas and ensure healthy - unpolluted environment, reduce risk disaster of natural hazards caused by CC and improve water security. After the industrialisation period, beside the problems of overpopulated neighbourhoods, high density, lack of infrastructure in all suburban settlements, city also started facing negative impacts of CC. United Nations Framework Convention on Climate Change was adopted in 1992 (UN, 1992) and so far held 25 conferences on climate change, and at 21 st conference Paris Agreement was adopted. Within this Agreement, importance of the ecosystems for the society and for adaptation and mitigation to CC was recognized. One of the obligations of the "member" countries was to define their post 2020 actions and targets for mitigation to CC as Nationally Determined Contribution (NDC). More than 1/2 member countries recognized and suggested NBS within their NDCs as a method for adaptation and mitigation. According to researchers, NBS could contribute to cost effective mitiga- 
tion with about $30 \%$ for reaching a goal set for reducing warming by 2030 (Seddon et al, 2019). CC is considered as one of the greatest threats of the $21 \mathrm{st}$ century, and both urban and rural areas are facing it, and it represents direct threat to human lives (health), ecosystems, life quality and wellbeing. Connection of NBS and CC is kind of partnership with nature (Naumann, 2014), and NBS should be part of all strategic and planning documents as an efficient way of $\mathrm{CC}$ adaptation and improvement of life quality. There are 2 approaches: use of NBS as a way of CC mitigation where ecosystems are used for GHG emission reduction, and NBS as a way of CC adaptation where focus is on preserving ecosystems which are necessary for human wellbeing and which could help with reducing negative impacts of CC (overheating, extreme weather - rainfalls...).

Considering all above mentioned, analyses of demographic, spatial and functional structure of the chosen settlements were conducted first, in order to determine their current state, natural resources they possess and their natural hazards vulnerability. Depending on the settlement characteristics and results of previous analyses, possible NBS are defined for each settlement, as well as adequate on site intervention depending on their spatial characteristics. These data are presented both graphical and tabular. Because aim of the use of NBS is to improve life quality in settlements, impact and area of improvement regarding environmental and social wellbeing was also discussed.

\section{CONTEXT: SETTLEMENTS IN SOUTH-EASTERN PART OF SERBIA}

According to OECD classification, more than $2 / 3$ of the Serbian territory is rural, and this paper discusses NBS impact on life quality improvement in rural settlements. In order to analyse possibilities for improvement of life quality in rural settlements, territory of south-eastern part of Serbia, which is also territory of the Region of Southern and Eastern Serbia was chosen. This area is mainly mountainous and hilly and it is characterized by great natural diversity. It occupies about $33 \%$ of total country territory, it is home to about $1 / 4$ of total Serbian population. According to data from Statistical Office of the Republic of Serbia (2019), there are total 1,973 settlements within 9 districts, and from this number only 46 are classified as "urban" while 1,927 are classified as "other", by default rural . Unfortunately, because of very diverse structure, characterized by negative demographic growth, and underdeveloped economy, share of this Region in national GDP is only $14,1 \%$, which makes it the least developed Region. There are 38 Municipalities in total, 10 cities and beside Niš and Bor all other are economically underdeveloped. This area is very diverse in terms of morphology, nature and ethnic structure. According to the classification of the settlements according to the percentage of their mountainous territory (Malobabic, 2003), within this area there are 4 municipalities whose territory is $100 \%$ in mountainous area, there are 10 municipalities and 2 cities whose over 50 $\%$ of territory surface is in mountainous area, and there are 5 cities and 10 municipalities whose territory surface is less than $50 \%$ in the mountainous area. Also, there is classification of settlements with aggravated conditions for agriculture production which is main activity in them (Ministry of Agriculture, Forestry and Water Management, 2018). First criterion is location in mountainous area, and according to it there are 7 cities and 33 municipalities, and according to two other criterions location on the outskirts of national parks or within them and location within devastated areas, there are 16 municipalities whose all settlements are facing this problem. Main problems that are faced by these settlements are certainly uneven economic and spatial development, especially high-hilly and marginalized settlements, negative demographic structure is much expressed because of lack of basic infrastructure, lack of job positions and lack of other services and activities for young people. All these problems affect quality of life which in case of these settlements is on a very low level. Other type of settlements that became suburbs are facing similar problems regarding economic development and infrastructure, but on the other hand they are overpopulated, with high density of built areas. These settlements are also facing negative impact of $\mathrm{CC}$ which has huge effect on life quality and wellbeing (Igic et al, 2020). For the purpose of this research, four different type of settlements were analysed: two settlements - seats of the municipalities: Gadžin Han and Trgovište, and two rural settlements in the Municipality Pantelej (city of Niš): Donja Vrežina - suburban settlement 
and Gornji Matejevac - large village. Gadžin Han (Nišava district) and Trgovište (Pčinja district) are seats of the same named municipalities, and they are classified as underdeveloped municipalities in hilly areas. In socialist period Donja Vrežina was rural village and during last decade of 20th century its territory "merged" with city's territory and became suburban settlement. Gornji Matejevac is a large village with 2,513 inhabitants and it is classified as hilly settlement. Main spatial, functional and demographic characteristics of analysed settlements are shown in Table 1.

_ Table 1: Spatial, functional and demographic characteristics of analysed settlements (source: Statistical Office of the Republic of Serbia, census 2011; data collected by author on site)

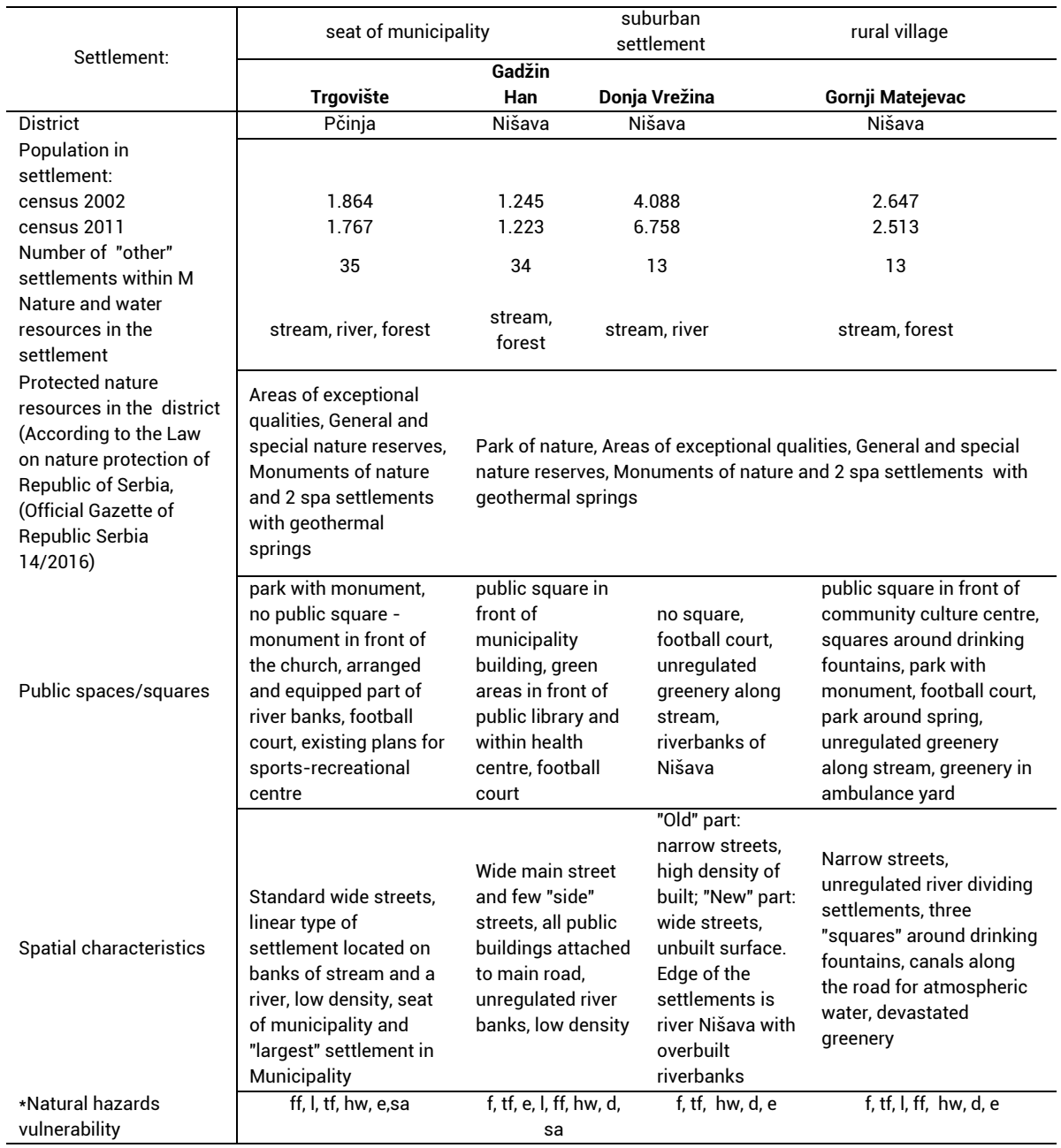

*f- Floods; tf- Torrential Floods; I- landslides; ff- Forest Fires; hw- Heat Waves;

f- Fires; d-Drought; sa- Seismic Activity; e- Erosion

\section{DISCUSSION}

According data in table 1, except Donja Vrežina, all other settlements are facing depopulation. Common for all the settlements is that they have irregular street network, except new part of Donja 
Vrežina. All the settlements are surrounded by diverse nature areas, of course except suburban settlement. They all have streams or rivers in their "centres" which are not used for recreation, except in case of Trgovište where part of the stream banks is regulated. All these settlements have some "public spaces" which are not used in an adequate manner and which are almost without greenery. Common for all of them is that there is a river flow on their territory and except of Gadžin Han, in other settlements it flows through densely populated areas. Regarding public squares which, except Gadžin Han where it was recently redesigned, are in bad condition and not used frequently. These areas could be equipped with urban furniture and water permeable paving, abandoned areas and neglected urban streams can be renatured and "revived". Public spaces could be redesigned in order to satisfy all microclimate demands and to provide adequate thermal comfort. Regarding surrounding forests and nature, it could be protected, and "peri-urban" parks along streams and on the forest outskirts could be designed. It is evident that these settlements are characterized by existing ecosystems that need to be preserved and "restored" and that there is a need for better management of them and rural land in general. Based on spatial and functional analyses of settlements, maps with spatial distribution of possible on-site NBS are presented (Fig 1).
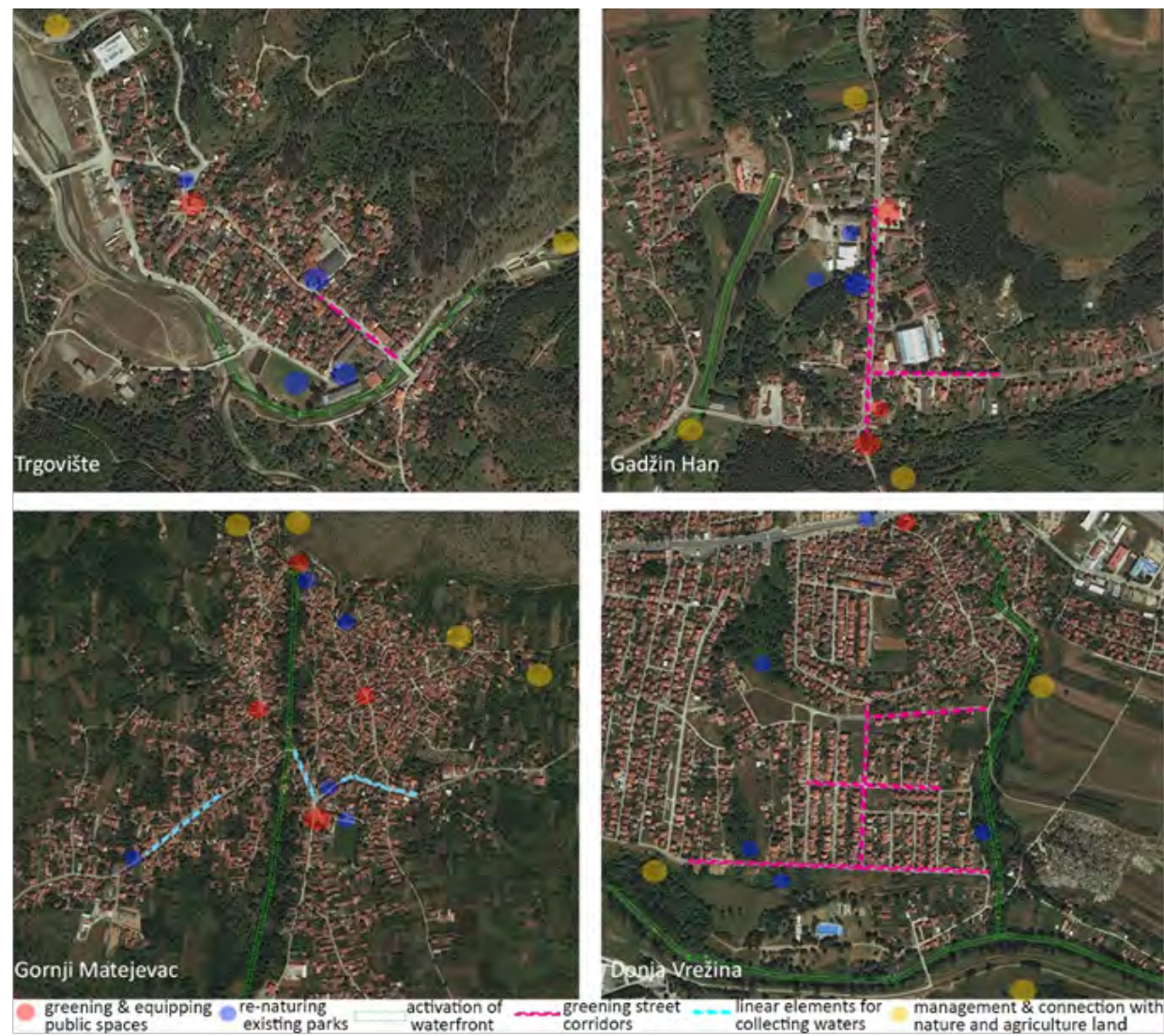

_ Figure 1: Possible NBS within analysed settlements (source: https://geosrbija.rs/, maps edited by authors)

Use of NBS in order to restore and manage existing ecosystems has huge impact on environmental and social well-being and it helps in increasing life quality. Based on proposed on-site NBS in all settlements, area of improvement regarding environmental and social benefits that tackles directly life quality and wellbeing is also presented (table 2). 
_ Table 2: Possibilities for use of NBS in analysed settlements and areas of improvement (source: by authors)

\begin{tabular}{|c|c|c|c|c|}
\hline \multirow[t]{2}{*}{ settlement: } & \multicolumn{2}{|c|}{ possibilities for apllying NBS } & \multicolumn{2}{|c|}{$\begin{array}{l}\text { area of improvement regarding residents } \\
\text { wellbeing and quality of life in settlement }\end{array}$} \\
\hline & NBS & on site intervention & environmental & social \\
\hline \multirow[t]{4}{*}{ Trgovište } & $\begin{array}{l}\text { greening and } \\
\text { equipping public } \\
\text { spaces, using } \\
\text { porous } \\
\text { pavement }\end{array}$ & $\begin{array}{l}\text { greening "square" around } \\
\text { monument in front of the } \\
\text { church, use of porous } \\
\text { pavement, greening street } \\
\text { with larger regulation } \\
\text { width }\end{array}$ & $\begin{array}{l}\text { managing thermal } \\
\text { comfort, improving air } \\
\text { quality, managing rain } \\
\text { runoff, reducing noise of } \\
\text { motor traffic }\end{array}$ & \multirow{4}{*}{$\begin{array}{c}\text { improving } \\
\text { mental and } \\
\text { physical health } \\
\text { of the residents, } \\
\text { improving social } \\
\text { interactions and } \\
\text { public } \\
\text { connectivity, } \\
\text { promoting } \\
\text { healthy lifestyles } \\
\text { and recreation, } \\
\text { creating safe } \\
\text { social } \\
\text { environment by } \\
\text { arranging and } \\
\text { equipping public } \\
\text { spaces, } \\
\text { promoting social } \\
\text { cohesion among } \\
\text { residents }\end{array}$} \\
\hline & $\begin{array}{l}\text { re-naturing } \\
\text { existing parks }\end{array}$ & $\begin{array}{c}\text { park with monument, } \\
\text { empty devastated green } \\
\text { areas }\end{array}$ & $\begin{array}{l}\text { Managing thermal } \\
\text { comfort, improving air } \\
\text { quality, managing rain } \\
\text { runoff, reducing noise of } \\
\text { motor traffic }\end{array}$ & \\
\hline & $\begin{array}{l}\text { activation of } \\
\text { waterfront / } \\
\text { restoration of } \\
\text { existing } \\
\text { landscape and } \\
\text { ecosystems }\end{array}$ & $\begin{array}{c}\text { regeneration and "renewal" } \\
\text { of river Pčinja and stream } \\
\text { Tripušnica banks, } \\
\text { adjusting them for safe } \\
\text { use of residents and also } \\
\text { regulation for flood } \\
\text { prevention }\end{array}$ & $\begin{array}{l}\text { improving water quality, } \\
\text { managing water cycle and } \\
\text { preventing floods, } \\
\text { preventing erosion and } \\
\text { management of soil, } \\
\text { improving air quality in the } \\
\text { settlement }\end{array}$ & \\
\hline & $\begin{array}{l}\text { management } \\
\text { and connection } \\
\text { with surrounding } \\
\text { nature and } \\
\text { agriculture } \\
\text { landscape }\end{array}$ & $\begin{array}{l}\text { formation of "peri-urban } \\
\text { parks" and better } \\
\text { connection and } \\
\text { management of } \\
\text { surrounding }\end{array}$ & $\begin{array}{l}\text { improvement of soil } \\
\text { quality, reduce of } \mathrm{GHG} \\
\text { emissions - decrease of } \\
\text { air pollution conserving } \\
\text { biodiversity }\end{array}$ & \\
\hline \multirow[t]{5}{*}{$\begin{array}{l}\text { Gadžin } \\
\text { Han }\end{array}$} & $\begin{array}{c}\text { greening and } \\
\text { equipping public } \\
\text { spaces, using } \\
\text { porous } \\
\text { pavement }\end{array}$ & $\begin{array}{l}\text { main square in front of } \\
\text { Municipality building }\end{array}$ & $\begin{array}{c}\text { managing thermal } \\
\text { comfort, managing runoff } \\
\text { in public spaces, creating } \\
\text { place with satisfying } \\
\text { micro-climate ambience }\end{array}$ & \multirow{5}{*}{$\begin{array}{c}\text { improving } \\
\text { mental and } \\
\text { physical health } \\
\text { of the residents, } \\
\text { improving social } \\
\text { interactions and } \\
\text { public } \\
\text { connectivity, } \\
\text { promoting } \\
\text { healthy lifestyles } \\
\text { and recreation, } \\
\text { creating safe } \\
\text { social } \\
\text { environment by } \\
\text { arranging and } \\
\text { equipping public } \\
\text { spaces, } \\
\text { promoting social } \\
\text { cohesion among } \\
\text { residents }\end{array}$} \\
\hline & $\begin{array}{l}\text { re-naturing } \\
\text { existing parks }\end{array}$ & $\begin{array}{l}\text { park in front of the library, } \\
\text { park within healthcare } \\
\text { centre, area of football } \\
\text { court }\end{array}$ & $\begin{array}{l}\text { Managing thermal } \\
\text { comfort, improving air } \\
\text { quality, managing rain } \\
\text { runoff, reducing noise of } \\
\text { motor traffic }\end{array}$ & \\
\hline & $\begin{array}{l}\text { activation of } \\
\text { waterfront / } \\
\text { restoration of } \\
\text { existing } \\
\text { landscape and } \\
\text { ecosystems }\end{array}$ & $\begin{array}{l}\text { regeneration and } \\
\text { activation of Kutinska river } \\
\text { banks, adjusting them for } \\
\text { safe use and regulation for } \\
\text { flood prevention }\end{array}$ & $\begin{array}{l}\text { improving water and air } \\
\text { quality, managing water } \\
\text { cycle and preventing } \\
\text { floods, preventing erosion } \\
\text { and management of soil, }\end{array}$ & \\
\hline & $\begin{array}{l}\text { greening street } \\
\text { corridors }\end{array}$ & $\begin{array}{l}\text { There are few streets with } \\
\text { large regulation width } \\
\text { where it is possible to } \\
\text { create "green" corridors }\end{array}$ & $\begin{array}{c}\text { managing thermal } \\
\text { comfort, improving air } \\
\text { quality, collect runoff } \\
\text { water from traffic network }\end{array}$ & \\
\hline & $\begin{array}{c}\text { management } \\
\text { and connection } \\
\text { with surrounding } \\
\text { nature and } \\
\text { agriculture } \\
\text { landscape } \\
\end{array}$ & $\begin{array}{l}\text { formation of "peri-urban } \\
\text { parks" and better } \\
\text { connection and } \\
\text { management of } \\
\text { surrounding nature and } \\
\text { agriculture land }\end{array}$ & $\begin{array}{l}\text { improvement of soil } \\
\text { quality, reduce of } \mathrm{GHG} \\
\text { emissions - decrease of } \\
\text { air pollution conserving } \\
\text { biodiversity, activation of } \\
\text { outskirts greenery belt }\end{array}$ & \\
\hline \multirow[t]{3}{*}{$\begin{array}{l}\text { Donja } \\
\text { Vrežina }\end{array}$} & $\begin{array}{l}\text { greening and } \\
\text { equipping public } \\
\text { spaces }\end{array}$ & $\begin{array}{l}\text { space around bus stop } \\
\text { where few stores are } \\
\text { located }\end{array}$ & $\begin{array}{l}\text { managing thermal } \\
\text { comfort, improving air } \\
\text { quality, reducing noise of } \\
\text { traffic }\end{array}$ & \multirow{3}{*}{$\begin{array}{c}\text { improving } \\
\text { mental and } \\
\text { physical health } \\
\text { of the residents, } \\
\text { improving social } \\
\text { interactions and } \\
\text { public } \\
\text { connectivity, } \\
\text { promoting } \\
\text { healthy lifestyles } \\
\text { and recreation, } \\
\text { creating safe } \\
\text { social, } \\
\text { promoting social } \\
\text { cohesion among } \\
\text { residents, } \\
\text { greening street }\end{array}$} \\
\hline & $\begin{array}{l}\text { re-naturing } \\
\text { existing parks }\end{array}$ & $\begin{array}{c}\text { greening area around } \\
\text { football court, greening } \\
\text { empty lots and creating } \\
\text { parks (creating "urban } \\
\text { forests") }\end{array}$ & $\begin{array}{c}\text { managing thermal } \\
\text { comfort, improving air } \\
\text { quality }\end{array}$ & \\
\hline & $\begin{array}{l}\text { activation of } \\
\text { waterfront / } \\
\text { restoration of }\end{array}$ & $\begin{array}{l}\text { regeneration stream } \\
\text { Matejevečka reka banks, } \\
\text { this river flows within built } \\
\text { core of the settlement, } \\
\text { activation and bringing } \\
\text { back to the residents } \\
\text { banks of the river Nišava ( } \\
\text { banks are overconstructed }\end{array}$ & $\begin{array}{l}\text { improving water quality } \\
\text { and prevent future } \\
\text { pollution, managing water } \\
\text { cycle and preventing } \\
\text { floods, preventing erosion } \\
\text { and management of soil, }\end{array}$ & \\
\hline
\end{tabular}




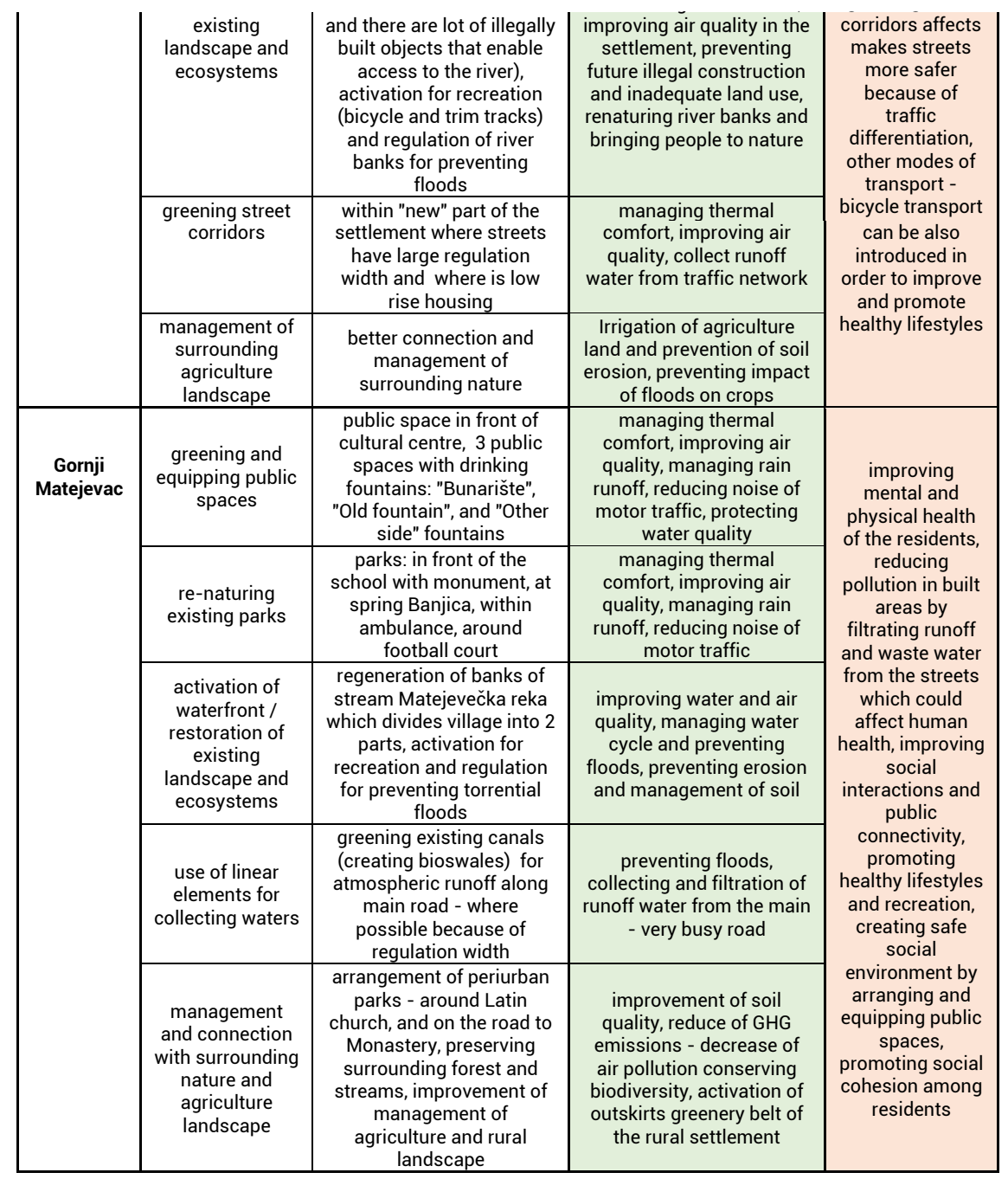

Analysed settlements have diverse ecosystems on their territory but they are not managed in good manner and they are often completely neglected, and in some situation devastated. Use of NBS could help to improve - restore existing ecosystems and their management and management of rural land in general. Challenges that are facing urban are the same for the rural areas but because of lack of knowledge, initiative and both strategic and planning documents this problem has not been overcome adequately. These settlements are all characterized as other - rural but they have different structure. Even though Trgovište and Gadžin Han are seats of municipalities, they face problems of depopulation and unfavourable life conditions for residents. Suburban settlement has other problem - increase in population which is not followed by infrastructure development and which led to usurpation of public spaces along the river banks of Nišava. Rural village Gornji Matejevac, has inherited narrow street network with small "squares" from Ottoman period which are completely paved and there are no green areas, and those squares that are located around some of the public buildings and drinking fountains are neglected.

Suggested intervention with implementation of NBS on the territory of these settlements could have huge impact on life quality in them. Greening and redesigning of public spaces and spaces in front 
of their important public buildings could make more attractive spaces for gathering of residents and could improve their social contacts and ensure social cohesion. On the other hand, it could help to manage thermal comfort because of overheating during summer, to create micro-climate friendly ambience which could be used by residents frequently even during summer months and it could help in reduction of air pollution. Existing parks could be re-natured and regenerated with more greenery in order to provide more environment friendly areas for recreation and gathering of residents. All of the settlements are located on the banks of rivers or streams which are completely neglected and devastated, even though they flow through "central" areas of the settlements. These flows are a great threat for floods and torrential floods which cause soil erosion and represent great threat to human lives, health of residents and built environment. Regeneration of "waterfronts" and regulation of flows could have positive impact on both environment in terms of improvement of water and air quality, improvement of green areas and creation of recreational areas. From social point of view, this could improve both mental and physical health of residents and recreation could promote healthy lifestyles. This flows could represent green corridors within settlements providing attractive ambiences and places for gathering on one hand and preventing possible negative impacts of floods on their surrounding territory on the other. In settlements with streets that have larger street regulation width (Donja Vrežina and Gadžin Han) greenery can be planted in order to create kind of "green barrier" between pedestrian and motor traffic, to reduce air and noise pollution. In Gornji Matejevac there are a canals for atmospheric and waste water which could be transformed into bioswales in order to reduce pollution.

Implementation of NBS could also improve management of agriculture and rural land. Main activity of the residents in most of the rural areas is agriculture and food production. $\mathrm{CC}$ has negative impact on crops because of overheating, extreme rainfalls and floods caused by surrounding streams and river. Use of these NBS and concepts related to nature could ensure better conditions for agriculture land and reduce vulnerability to natural hazards. Management of rural land can be improved, which would affect economy and could create job positions which could prevent depopulation and improve quality of life. According to the analyses, it is obvious that implementation of NBS can have multiple benefits on environment, social cohesion and economy which directly improves life quality in devastated rural areas.

\section{CONCLUSION}

After the industrialization process, and in the second half of the 20th century during socialism period, cities were seen as a "better" place for living and their territory started spreading and merging with surrounding settlements. As a negative consequence, some rural settlements faced negative trend of depopulation and marginalization, which led to decrease of life quality in them. These settlements are characterized by very rich and diverse natural resources which are often neglected. Because of reduced life quality in these settlements, unemployment rate and lack of infrastructure, there are constant migrations of population from them. In order to improve life quality in rural settlements, use of NBS is discussed and benefits of implementation were analysed.

According conducted analysis, it is obvious that NBS could be applied also in rural settlements as in the urban, and that they could improve life quality. For the purpose of this analysis, four settlements were chosen and potentials for NBS were explored within their territory. Results of the analysis show that these interventions can be applied in order to restore existing ecosystems, preserve existing natural resources and to implement innovative solutions in creating micro-climate friendly ambiences of neglected public spaces in the analysed settlements. Implementation of NBS would certainly have impact on life quality, wellbeing and both mental and physical health of residents. With these interventions neglected areas are regenerated, and settlements become less vulnerable to natural hazards caused by CC. In order to raise awareness of residents of benefits of NBS implementation, it is necessary that NBS become part of planning and strategic documents on local level, and to organize educational courses within residents. Many of these solutions can be applied 
locally and they are not large "burden" for the budget. For all of Municipalities on whose territories are located analysed settlements, spatial plans, plans of general regulation and local strategies for sustainable development are adopted and within them "natural" potential is recognized. None of these documents is recognizing possibilities for use of NBS as efficient and cost effective solution for increasing life quality and facing $\mathrm{CC}$ negative impacts. In order to improve planning and strategic documents on local level, departments within local authorities could be organized with aim to promote NBS and to raise awareness of residents. Workshops and on-site actions could be organized in order to involve local residents in decision making processes and to empower local community. Possibilities of NBS implementation and their impact on life quality can be further investigated and expanded to other type of rural settlements and different simulations can be made in order to choose adequate solution to implement in every settlement.

\section{REFERENCES}

- Cohen-Shacham E., Walters Gretchen, Janzen Christine and Stewart Maginnis (eds.) 2016. Nature-based Solutions to address global societal challenges. Gland, Switzerland: IUCN

_ Eggermont Hilde, Balian Estelle, Azevedo José Manuel N., Beumer Victor, Brodin Tomas, Claudet Joachim, Fady Bruno, Grube Martin, Keune Hans, Lamarque Penelope, Reuter Katrin, Smith, Matt, van Ham Chantal, Weisser W.Wolfgang and Xavier Le Roux. 2015. "Nature-based Solutions: New Influence for Environmental Management and Research in Europe". GAIA 24(4): 243-248.

- European Commission. 2015. Towards an EU Research and Innovation policy agenda for Nature-Based Solutions and Re-Naturing cities: Final Report of the Horizon 2020 expert group on "Nature-Based Solutions and Re-Naturing cities (full version). Brussels: EC

- Howard, Ebenezer. 1898. To-morrow a peaceful path to real reform. London: Swann Sonnenschein

- Igic Milica, Mitkovic Petar, Dinic Brankovic Milena, Đekić Jelena and Mihailo Mitković. 2020. Impact of Climate Change on rural development and rural built environment: case study settlements within the Region of the Southern and Eastern Serbia. IOP Conference Series: Earth and Environmental Science. 410. 012007. 10.1088/1755-1315/410/1/012007.

- IUCN. 2013. The IUCN Programme 2013-2016. Gland: International Union for the Conservation of Nature

_- Kabisch Nadja \& Annerstedt van den Bosch. 2017. Urban Green Spaces and the Potential for Health Improvement and Environmental Justice in a Changing Climate. Chapter 12 in: Nature-based Solutions to Climate Change in Urban Areas - Linkages of science, society and policy. Edition: 1st, Editors: Nadja Kabisch, Aletta Bonn, Horst Korn, Jutta Stadler, pp.237-253, Published by Springer

- Lafortezza Raffaele, Chenb Jiquan, Konijnendijk van den Boschc Cecil and Thomas B. Randrupd. 2018. Nature-based solutions for resilient landscapes and cities. Environmental Research. Volume 165, pp 431 44

- Lafortezzaa Raffaele and Giovanni Sanesi. 2019. Nature-based solutions: Settling the issue of sustainable urbanization. Environmental Research 172 (2019) pp. 394-398

- Maes Joachim \& Sander Jacobs. 2015. Nature-Based Solutions for Europe's Sustainable Development. Conservation letters. DOI: 10.1111/conl.12216

- MacKinnon Kathy, Sobrevila Claudia and Valerie Hickey. 2008. The World Bank report, Biodiversity, Climate Change and Adaptation: Nature-Based Solutions from the World Bank Portfolio. Washington: The International Bank for Reconstruction and Development / THE WORLD BANK

- Malobabić Radomir .2003. Planinska područja nerazvijeni prostori u Republici Srbiji, Treći naučno stučni skup "Selo u novim razvojnim uslovima”, Beograd: Udruženje Urbanista Srbije, pp.77-87

- Ministry of Agriculture, Forestry and Water Management. 2018. Regulation on designation of areas with aggregated working conditions in agriculture. Official gazette of Republic Serbia Nr 102/18

- Naumann Sandra, Kaphengst Timo, McFarland Keighley and Jutta Stadler. 2014. The challenge of climate change - partnering with nature: Nature-based approaches for climate change mitigation and 
adaptation. Bonn: German Federal Agency for Nature Conservation

_ Nesshöver Carsten, Assmuth Timo, N. Irvine Katherine, M. Rusch Graciela, A.Waylen Kerry, Delbaere Ben, Haase Dagmar, Jones-Walters Lawrence, Keune Hans, Kovacs Eszter, Krauze Kinga, Külvik Mart, Rey Freddy, van Dijk Jiska, Inge Vistad Odd, E.Wilkinson Mark and Heidi Wittmer. 2017. The science, policy and practice of nature-based solutions: An interdisciplinary perspective. Science of the Total Environment 579 (2017) pp.1215-1227

_ Pauleit Stephan, Zölch Teresa, Hansen Rieke, Barfoed Randrup Thomas and Cecil Konijnendijk van den Bosch. 2017. "Nature-Based Solutions and Climate Change - Four Shades of Green". Chapter 3 in: Nature-based Solutions to Climate Change in Urban Areas - Linkages of science, society and policy. Edition: 1st, Editors: Nadja Kabisch, Aletta Bonn, Horst Korn, Jutta Stadler, pp.237-253, Published by Springer

_ Rutt Rebecca Leigh and Natalie Marie Gulsrud. 2016. Green justice in the city: A new agenda for urban green space research in Europe. Urban Forestry \& Urban Greening 19 (2016) 123-127

- Seddon Nathalie, Sengupta Sandeep, García-Espinosa Maria, Hauler Irina, Herr Dorothee and Ali Raza Rizvi. 2019. Nature-based Solutions in Nationally Determined Contributions: Synthesis and recommendations for enhancing climate ambition and action by 2020. Gland, Switzerland and Oxford, UK: IUCN and University of Oxford

_ Statistical Office of the Republic of Serbia .2019. Profile of the Region of the Southern and Eastern Serbia. Accessed February 25,

_ http://devinfo.stat.gov.rs/SerbiaProfileLauncher/files/profiles/sr/1/DI_Profil_Region\%20Juzne\%20 i\%20lstocne\%20Srbije_EURSRB002002.pdf

_ United Nations. 1992. United Nations framework convention on climate change. Geneva: UN

_ Vujcic Maja, Tomicevic-Dubljevic Jelena, Grbic Mihailo, Lecic-Tosevski Dusica, Vukovic Olivera and Oliver Toskovic. 2017. Nature based solution for improving mental health and well-being in urban areas. Environmental Research 158 (2017) pp. 385-392 